\title{
Desain Didaktis Materi Trigonometri dalam Upaya Meminimalisir Hambatan Belajar Siswa
}

\author{
Ena Sakinah $^{1}$, Darwan ${ }^{2}$, Arif Abdul Haqq ${ }^{3}$ \\ 1,2,3 Tadris Matematika, Institut Agama Islam Negeri Syekh Nurjati Cirebon \\ e-mail: enasakinah@syekhnurjati.ac.id
}

\begin{abstract}
ABSTRAK. Penelitian ini bertujuan untuk menghasilkan sebuah desain didaktis pada materi trigonometri. Metode yang digunakan dalam penelitian ini adalah design didactical research yang dikembangkan oleh Suryadi. Metode pengumpulan data yang digunakan dalam penelitian ini, yaitu: tes, wawancara, observasi, dokumentasi, dan angket. Penelitian ini dilakukan pada kelas XI IIK sebagai kelas yang telah menerima materi trigonometri untuk mengetahui hambatan belajar yang dialami siswa pada materi trigonometri. Setelah ditemukannya hambatan belajar yang dialami siswa, peneliti menyusun desain didaktis hipotesis yang disesuaikan dengan hambatan belajar siswa dan alur pembelajaran siswa. Desain didaktis hipotesis ini diimplementasikan kepada kelas X IIK 2 sebagai kelas implementasi yang belum pernah mendapatkan materi trigonometri. Dari hasil analisis uji hambatan belajar preimplentasi dan pascaimplementasi terdapat penurunan hambatan belajar sehingga hambatan belajar dapat terminimalisir dengan dibuatnya desain didaktis hipotesis.
\end{abstract}

Kata kunci: Desain Didaktis; Hambatan Belajar; Materi Trigonometri.

\section{PENDAHULUAN}

Matematika dalam dunia pendidikan merupakan salah satu mata pelajaran penting, dari jenjang pendidikan formal yang terendah hingga yang tertinggi pelajaran matematika mutlak harus dipelajari (Muslim, Mulyani, \& Prabawati, 2017). Dalam mempelajari matematika, materi prasyarat harus dipahami dengan benar terlebih dahulu sebelum belajar materi selanjutnya yang lebih tinggi tingkatannya, karena semakin tinggi tingkatannya maka akan semakin sulit tingkat kesukarannya sehingga jika siswa sudah memahami materi prasyaratnya maka siswa akan lebih mudah memahami materi selanjutnya. Ketika siswa mempelajari matematika siswa harus bisa menyelesaikan masalah matematika, sehingga siswa akan berpikir dan mencari solusi dari permasalahan tersebut (Kusaeri, Lailiyah, Arrifadah, \& Hidayati, 2018).

Belajar adalah suatu proses perubahan tingkah laku individu melalui interaksi dengan lingkungan (Yamin, 2007). Belajar merupakan proses perubahan yang bersifat positif sehingga pada akhirnya akan diperoleh keterampilan dan pengetahuan yang baru. Belajar berarti tidak hanya gurunya saja yang harus aktif dan kreatif, tetapi peserta didik juga harus ikut berpasrtisipasi dalam pembelajaran agar pembelajaran dapat berjalan dengan baik. Untuk mengikuti kegiatan belajar mengajar, seorang peserta didik biasanya membutuhkan motivasi belajar, apalagi ini terkait dengan pelajaran matematika yang kebanyakan peserta didik tidak menyukainya. Belajar dapat dikatakan berhasil jika materi pembelajaran dapat dicerna dengan baik oleh peserta didik yang diperoleh dari pendidik. Tetapi, dalam proses pembelajaran tentunya pasti ada hambatan-hambatan yang dialami oleh peserta didik yang lebih dikenal dengan istilah learning obstacle. Selain learning obstacle guru juga harus memperhatikan learning trajectory siswa.

Hambatan belajar merupakan suatu halangan yang memperlambat fokus usaha dalam menerima pembelajaran. Banyak hambatan-hambatan yang dialami peserta didik dalam belajar. Hambatan belajar atau learning obstacle ini terjadi karena tiga faktor, yaitu hambatan ontogeni 
(kesiapan mental belajar), didaktik (pengajaran guru atau bahan ajar), dan epistimologi (pengetahuan siswa yang memiliki konteks terbatas) (Sulistiawati, Suryadi, \& Fatimah, 2015).

Pada kegiatan proses belajar mengajar setidaknya ada tiga hal yang saling berhubungan, yaitu peserta didik, pendidik, dan materi pelajaran. Hubungan ketiga hal tersebut harus diperhatikan oleh guru ketika guru merancang desain pembelajaran. Dalam merancang suatu pembelajaran di sekolah itu bukanlah hal yang mudah, seorang pendidik tentu harus kreatif dan inovatif agar dalam pelaksanaan pembelajaran tersebut menarik. Dalam merancang pembelajaran, ada teknik-teknik dan langkah-langkah dalam membuatnya, seperti harus lebih dulu mengetahui karakter yang dimiliki oleh siswa ketika akan menerapkan suatu model pembelajaran.

Dalam mengajar, seorang pendidik harus memperhatikan hambatan-hambatan belajar yang dialami oleh peserta didik dalam belajar, terutama pada materi trigonometri dimana siswa seringkali kebingungan dalam materi tersebut. Kesulitan tersebut juga terjadi karena kurangnya pemahaman siswa dalam menghubungkan materi sub bab yang satu dengan materi sub bab yang lainnya. Banyak siswa yang tidak suka dengan mata pelajaran matematika, salah satu faktor yang berpengaruh adalah bahan ajar, media, dan pemakaian metode yang digunakan guru kurang membawa peserta didik untuk terlibat langsung dalam pembelajaran (Anggraini \& Masykur, 2018). Hal ini disebabkan karena materi trigonometri mengandung banyak sub bab yang saling berkaitan khususnya materi aturan sinus dan aturan cosinus yang sangat sulit dipahami oleh siswa, ini disebabkan karena peserta didik cepat lupa dengan materi yang sebelumnya diberikan (Putra \& Anggraini, 2016). Oleh karena itu, peneliti ingin membuat desain didaktis materi trigonometri yang menganalisis terlebih dahulu hambatan belajar siswa sehingga materi trigonometri akan menjadi mudah dipahami oleh siswa.

Didaktik berasal dari bahasa Yunani didaskein yang berarti pengajaran dan didaktikos berarti pandai mengajar. Didaktik yang dimaksud adalah ilmu mengajar yang memberikan prinsip-prinsip tentang cara-cara menyampaikan bahan pelajaran sehingga dikuasai dan dimiliki oleh anak-anak. (Nasution, 2010). Didaktik berasal dari bahasa Yunani didasko yang asal katanya adalah didaskein atau pengajaran yang berarti perbuatan atau aktivitas yang menyebabkan timbulnya kegiatan dan kecakapan baru pada orang lain. Didaktikus berarti pandai mengajar, sedang didaktika berarti saya mengajar. (Team Didaktik Metodik Kurikulum IKIP Surabaya, 1987). Secara etimologis, didaktik berasal dari bahasa Yunani didaskein yang memiliki arti mengajar. Sedangkan secara terminologi, didaktik memiliki arti ilmu untuk menanamkan pengetahuan kepada siswa dan mahasiswa dengan cara yang cepat dan tepat sehingga siswa dan mahasiswa mudah memahami dan mengetahuinya. (Yamin, 2007). Dari beberapa pengertian tersebut, dapat disimpulkan bahwa didaktik adalah ilmu mengajar yang memberikan uraian tentang kegiatan proses belajar mengajar yang disampaikan dengan baik sehingga dapat diterima dengan mudah oleh orang yang menerima pelajaran.

Istilah didaktik ini telah muncul pada abad ke 17 oleh seseorang yang bernama Johan Amos Comenius (1592 - 1671). Ia dijuluki seorang didaktikus. Ia dilahirkan di Moravia pada tahun 1592 dan meninggal di Amsterdam pada tahun 1671. Comenius sangat berjasa dalam mengembangkan ilmu mengajar di dunia pendidkan. Dikala hidupnya, ia diundang ke Inggris dan Swedia untuk membuat buku dan metode pembelajaran di sekolah-sekolah. Di Inggris ia menulis buku Pansophia (ilmu pengetahuan dan kepemimpinan). Karya-karyanya yang terkenal adalah Didactica Magna (ilmu mengajar), dan Janua Linguarum Reserata (pintu terbuka untuk bahasa-bahasa), Prbis Pictus (dunia dalam gambar). (Team Didaktik Metodik Kurikulum IKIP Surabaya, 1987)

Desain didaktis merupakan rancangan bahan ajar yang disusun berdasarkan penelitian learning obstacle (Annizar \& Suryadi, 2016). Learning obstacle adalah hambatan belajar yang dialami oleh siswa dalam belajar. Jika siswa mengalami hambatan dalam proses belajarnya maka hambatan itu dapat menyebabkan siswa mengalamai kegagalan atau setidaknya kurang berhasil dalam mencapai tujuan belajar (Zad, 2018).

Menurut Brousseau hambatan belajar ini terbagi ke dalam tiga jenis (Sulistiawati et al., 2015), yaitu: Ontogenical learning obstacle, yaitu kesulitan belajar siswa berdasarkan psikologis atau dari segi mental siswanya. Epistemological learning obstacle, yaitu kesulitan belajar siswa terhadap materi 
karena materi yang ditangkap oleh siswa tidak lengkap. Hal ini disebabkan oleh siswa yang hanya menganggap penting pengetahuan yang baru saja, sehingga ketika diberikan persoalan baru oleh gurunya peserta didik tidak menggunakan pengetahuan sebelumnya. Didactical learning obstacle, yaitu kesulitan belajar siswa yang terjadi karena kekeliruan penyajian dari gurunya.

Selain learning obstacle, ada juga yang dinamakan learning trajectory. Learning trajectory adalah suatu rangkaian kegiatan yang disiapkan oleh guru untuk menyampaikan materi kepada peserta didik yang disesuaikan dengan kemampuan peserta didiknya. Learning trajectory memberikan petunjuk bagi guru untuk menentukan dan merumuskan tujuan-tujuan pembelajaran yang akan dicapai, sehingga guru dapat membuat strategi atau langkah-langkah yang akan digunakan untuk mewujudkan tujuan-tujuan tersebut (Nikmaturrahmah, 2018).

Metapedadiktik terdiri dari tiga komponen penting, yaitu kesatuan, fleksibilitas, dan koherensi atau pertalian logis (Sulistiawati et al., 2015). Kesatuan maksudnya guru mampu memandang sisi-sisi segitiga didaktis yang dimodifikasi sebagai sesuatu yang utuh. Fleksibilitas adalah antisipasi yang sudah disiapkan oleh guru disesuaikan dengan didaktis pedagogis. Koherensi maksudnya situasi didaktis yang berkembang pada tiap milieu hingga muncul situasi yang berbedabeda, maka perbedaan-perbedaan situasi tersebut harus dikelola sehingga perubahan situasi selama proses pembelajaran berjanal dengan lancar dan mengarah dalam pencapaian tujuan. Dari ketiga komponen tersebut dapat disimpulkan bahwa seorang guru harus memiliki kemampuan tertentu dalam menciptakan situasi didaktis. (Nasihah, 2018)

Pada proses pembelajaran terdapat hubungan antara pendidik dengan peserta didik yang disebut dengan hubungan pedagogis (HP), hubungan antara peserta didik dengan materi pelajaran yang disebut hubungan didaktis (HD), dan hubungan antara pendidik dengan materi pelajaran yang disebut dengan antisipasi didaktis dan pedagogik (ADP). Hubungan tersebut dapat disajikan dalam segitiga didaktis pada gambar berikut (Suryadi, 2010):

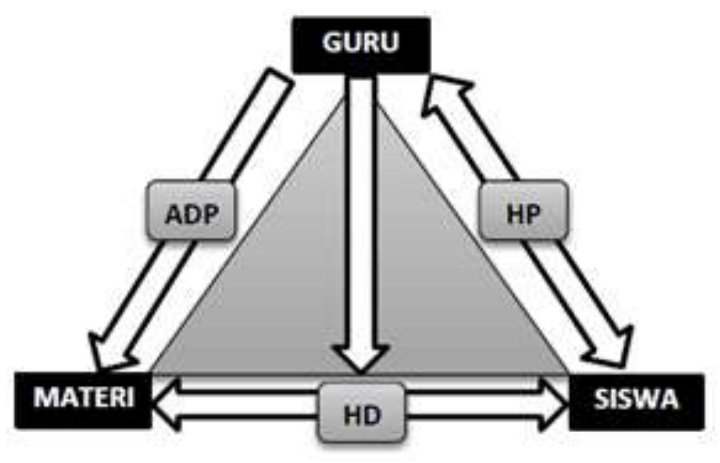

Gambar 1 Segitiga Didaktis

Segitiga didaktis tersebut menekankan pada analisis metapedadiktik, yaitu kemampuan guru dalam menganalisis hubungan pendidik dengan peserta didik, pendidik dengan materi, dan peserta didik dengan materi yang diilustrasikan dengan segitiga didaktis yang menghasilkan sebuah desain didaktis. Dari tiga langkah berpikir guru tersebut dapat dirangkai dalam suatu kegiatan penelitian yang disebut didactical design research (DDR). (Suryadi, 2010). Adapun teori belajar yang digunakan adalah

\section{Teori Kontruktivisme}

Belajar menurut teori kontruktivisme bukanlah sekadar menghafal, akan tetapi proses mengkontruksi pengetahuan melalui pengalaman (Sanjaya, 2008). Pengetahuan merupakan proses kontruksi yang dilakukan oleh setiap individu. Pengetahuan ini dimiliki oleh setiap individu yang bukan berasal dari pemberian orang lain. Menurut teori konstruktivisme, pengetahuan seseorang itu terbentuk dari pengetahuannya sendiri yang didapat dari pengalaman dirinya dalam berinteraksi dengan orang lain. 


\section{Teori Piaget}

Dalam teorinya Piaget memandang bahwa proses berpikir sebagai aktivitas gradual dari fungsi intelektual dari konkret menuju abstrak (Wahab, 2015). Struktur kognitif merupakan pola perkembangan fisiologi dan pola kegiatan mental yang mendasari aktivitas khusus yang terjadi di dalam pikiran serta berhubungan dengan fase-fase perkembangan anak (Jamaris, 2013). Dalam hal ini teori belajar Piaget ini memadukan antara perilaku dan dan aspek-aspek perkembangan koginitif.

\section{Teori Vygotsky}

Ide penting yang dapat diambil dari teori Vygotsky adalah scaffolding yaitu pemberian sejumlah besar bantuan kepada seseorang siswa selama tahap awal pembelajaran dan kemudian siswa tersebut mengambil alih tanggung jawab yang semakin besar segera setelah ia dapat melakukannya. Bantuan tersebut dapat berupa petunjuk, peringatan atau dorongan yang memungkinkan siswa tumbuh sendiri (Ningsih, 2014).

Vygotsky menekankan pentingnya interaksi sosial dengan orang-orang lain terlebih yang punya pengetahuan lebh baik dan sistem yang secara kultural telah berkembang dengan baik (Holisin, 2016). Hal ini sejalan dengan metode pembelajaran yang akan digunakan pada pembelajaran, yaitu diskusi kelompok.

\section{METODE}

Metode penelitian yang penulis lakukan adalah penelitian didactical design research yang dikembangkan oleh Suryadi. Penelitian ini terdiri dari tiga tahapan, yaitu tahap analisis situasi didaktis yang membahas tentang analisis learning obstacle siswa dan analisis learning trajectory siswa, tahap analisis metapedadiktis yang membahas tentang penerapan desain didaktis hipotesis yang dibuat berdasarkan learning obstacle siswa dan learning trajectory siswa, dan tahap analisis retrospektif yang membahas tentang perbaikan desain didaktis yang telah diimplementasikan.

Dalam penelitian ini, peneliti menggunakan instrumen sebagai berikut:

Tes

Tes adalah sekumpulan pertanyaan atau latihan yang digunakan untuk mengukur kemampuan yang dimiliki oleh individu ataupun kelompok. Penelitian ini, tes digunakan untuk menguji learning obstacle dan mengetahui hasil belajar peserta didik.

\section{Wawancara}

Wawancara yang akan digunakan dalam penelitian ini adalah wawancara terbuka tertutup. Wawancara ini merupakan gabungan wawancara terbuka dan tertutup (Emzir, 2012). Wawancara ini digunakan untuk mengetahui lebih mendalam tentang learning obstacle siswa. Wawancara ini, peneliti akan menggunakan alat perekam.

\section{Observasi}

Observasi adalah suatu kegiatan mencari data yang dapat digunakan untuk memberikan suatu kesimpulan atau diagnosis. Observasi dapat dilakukan hanya pada perilaku atau sesuatu yang tampak, sehingga potensi perilaku seperti sikap, pendapat jelas tidak dapat diobservasi. (Suharsaputra, 2012). Penelitian ini, observasi akan peneliti gunakan untuk mengetahui penerapan desain didaktis materi trigonometri yang disusun berdasarkan learning obstacle dan learning trajectory. 


\section{Dokumentasi}

Dokumentasi adalah benda tertulis yang dapat diberikan berbagai keterangan yang berguna sebagai alat bukti. Teknik dokumentasi ini akan peneliti gunakan dalam mendesain pembelajaran pada materi trigpnometri, yaitu tes awal yang ada dua tipe, pedoman wawancara, hasil wawancara, dan desain didaktis empirik.

\section{Angket}

Angket adalah sejumlah pertanyaan tertulis yang digunakan untuk memperoleh informasi dari responden dalam arti laporan tentang pribadinya. Angket yang akan peneliti gunakan adalah angket tertutup sehingga akan mempermudah responden untuk mengisinya. Pada penelitian ini angket digunakan untuk mengetahui penerapan didaktis hipotesis materi trigonometri yang disusun berdasarkan learning obstacle dan learning trajectory. Angket yang digunakan adalah angket dengan skala likert seperti ketentuan tabel dibawah ini (Sugiyono, 2013):

Tabel 1 Skala Likert

\begin{tabular}{ccc}
\hline No & Persentase & Kriteria \\
\hline $\mathbf{1}$ & $1-20$ & Sangat Lemah \\
$\mathbf{2}$ & $21-40$ & Lemah \\
$\mathbf{3}$ & $41-60$ & Cukup \\
$\mathbf{4}$ & $61-80$ & Kuat \\
$\mathbf{5}$ & $81-100$ & Sangat Kuat \\
\hline
\end{tabular}

\section{HASIL DAN PEMBAHASAN}

Penelitian ini terdiri dari tiga tahapan, yaitu:

\section{Tahap Analisis Situasi Didaktis}

Tahapan ini peneliti menentukan bahan penelitian yang ada pada tingkat sekolah menengah atas (SMA) atau sederajat pada semester genap karena yang akan diteliti adalah desain didaktis pada sekolah tingkat sekolah menengah atas (SMA) atau sederajat dan peneliti memilih materi trigonometri karena kebanyakan siswa yang telah mempelajari materi trigonometri kurang memahami materi tersebut.

Alur materi yang akan dibuat desain didaktisnya, yaitu: sudut dan sistem koordinat cartesius, perbandingan trigonometri, identitas trigonometri, rumus jumlah atau selisih fungsi trigonometri, dan penerapan trigonometri. Peneliti menyusun instrumen uji learning obstacle berupa 10 soal uraian yang terkait dengan sub bab materi yang telah dipilih untuk dibuat desain didaktisnya. Soal uji learning obstacle tersebut diujikan kepada siswa kelas XI IIK yang telah mendapatkan materi trigonometri. Dari uji learning obstacle tersebut, peneliti mendapatkan gambaran hambatan belajar yang dialami siswa. Hambatan belajar dari hasil identifikasi kekeliruan soal disajikan pada tabel berikut: 
Tabel 2 Hambatan Belajar Siswa

\begin{tabular}{|c|c|}
\hline $\begin{array}{c}\text { Tipe } \\
\text { Hambatan } \\
\text { Belajar }\end{array}$ & Hambatan Belajar \\
\hline Epistimologi & $\begin{array}{l}\text { Siswa belum memahami konsep bilangan positif (+) atau negatif (-) pada setiap } \\
\text { kuadran. } \\
\text { Siswa belum sepenuhnya paham konsep interval pada setiap kuadran. } \\
\text { Siswa belum sepenuhnya paham konsep perbandingan trigonometri. } \\
\text { Siswa belum memahami konsep dalil phytagoras. } \\
\text { Siswa belum sepenuhnya paham terhadap rumus dari jumlah atau selisih } \\
\text { trigonometri. } \\
\text { Siswa belum sepenuhnya paham konsep perbandingan trigonometri pada sudut- } \\
\text { sudut istimewa. } \\
\text { Siswa belum sepenuhnya paham konsep dalil phytagoras. } \\
\text { Siswa belum sepenuhnya paham konsep trigonometri pada segitiga. } \\
\text { Siswa belum paham mengenai konsep perbandingan trigonometri. } \\
\text { Siswa belum sepenuhnya paham rumus identitas trigonometri. } \\
\text { Siswa belum sepenuhnya paham konsep sistem koordinat cartesius. } \\
\text { Siswa belum sepenuhnya paham konsep kuadran pada sistem koordinat cartesius. } \\
\text { Siswa belum sepenuhnya paham konsep suatu sudut pada sistem koordinat } \\
\text { cartesius. } \\
\text { Siswa belum sepenuhnya paham rumus pada penerapan trigonometri dalam } \\
\text { kehidupan sehari-hari. } \\
\text { Siswa belum sepenuhnya paham konsep penerapan trigonometri dalam kehidupan } \\
\text { sehari-hari. }\end{array}$ \\
\hline
\end{tabular}

Berdasarkan hasil dari analisis yang dilakukan peneliti terhadap respon jawaban siswa dalam uji learning obstacle dan learning trajectory siswa maka akan disusun sebuah rancangan desain didaktisnya pada materi trigonometri agar dapat meminimimalisir hambatan-hambatan belajar siswa yang telah peneliti temukan pada uji learning obstacle sehingga diharapkan untuk ke depannya hambatan-hambatan belajar yang ditemukan peneliti tersebut tidak terjadi lagi kepada siswa. Dalam rancangan desain didaktis hipotesis ini peneliti memilih menggunakan model pembelajaran student team achievement development (STAD) dengan belajar kelompok, karena dari data yang didapatkan dari wawancara kepada siswa diperoleh bahwa siswa pada kelas X IIK 2 terbiasa belajar dengan metode dari gurunya mengumpulkan poin sebanyak-banyaknya sehingga siswa termotivasi belajarnya dengan mengumpulkan poin tersebut. Dalam rancangan desain didaktis hipotesis yang dibuat peneliti ini juga akan diterapkan metode pengumpulan poin, hanya saja pengumpulan poin tersebut secara berkelompok.

\section{Tahap Analisis Metapedadiktis}

Tahapan ini peneliti mengimplementasikan desain didaktis hipotesis yang telah dirancang berdasarkan learning trajectory dan learning obstacle siswa. Desain didaktis hipotesis tersebut diimplementasikan kepada kelas X IIK 2 yang belum pernah mendapatkan materi trigonometri. Pada tahapan ini peneliti menganalisis situasi didaktis siswa pada saat desain didaktis hipotesis diimplementasikan. Berikut gambaran situasi didaktis pada saat pembelajaran: 
Tabel 3 Antisipasi Didaktis dan Respon Siswa

Hambatan Belajar
Siswa belum memahami
konsep bilangan positif ( + )
atau negatif (-) pada setiap
kuadran.
Siswa belum sepenuhnya
paham konsep interval pada
setiap kuadran.
Siswa belum sepenuhnya
paham konsep
perbandingan trigonometri.
Siswa belum memahami
konsep dalil phytagoras.
Siswa belum sepenuhnya
paham terhadap rumus dari
jumlah atau selisih
trigonometri.
Siswa belum sepenuhnya
paham
perbandingan trigonometri
pada sudut-sudut istimewa.

Siswa belum sepenuhnya paham konsep dalil phytagoras.

Siswa belum sepenuhnya paham konsep trigonometri pada segitiga.

Siswa belum paham mengenai konsep perbandingan trigonometri.

Siswa belum sepenuhnya paham rumus identitas trigonometri.

Siswa belum sepenuhnya paham konsep sistem koordinat cartesius.

Siswa belum sepenuhnya paham konsep kuadran pada sistem koordinat cartesius.

Siswa belum sepenuhnya paham konsep suatu sudut pada sistem koordinat cartesius.

Siswa belum sepenuhnya paham rumus pada penerapan trigonometri dalam kehidupan sehari-hari. Siswa belum sepenuhnya
Antisipasi Didaktis

Respon Siswa

Siswa diingatkan kembali terkait pembahasan sudut dan sistem koordinat cartesius.

Siswa diingatkan kembali terkait pembahasan perbandingan trigonometri.

Siswa diingatkan kembali terkait pembahasan rumus jumlah atau selisih fungsi trigonometri.

Siswa diingatkan kembali terkait pembahasan perbandingan trigonometri pada sudut-sudut istimewa.

Siswa diingatkan kembali terkait pembahasan perbandingan trigonometri.

Siswa diingatkan kembali terkait pembahasan rumus identitas trigonometri.

Siswa diingatkan kembali terkait pembahasan sudut dan sistem koordinat cartesius.

Siswa diingatkan kembali terkait pembahasan rumus jumlah atau selisih fungsi trigonometri.
Siswa sudah mampu memahami konsep bilangan positif $(+)$ atau negatif $(-)$ pada setiap kuadran.

Siswa sudah mampu memahami konsep interval pada setiap kuadran.

Siswa sudah mampu memahami konsep perbandingan trigonometri tetapi masih ada kekeliruan.

Siswa sudah mampu memahami konsep dalil phytagoras.

Siswa belum mampu memahami rumus dari jumlah atau selisih trigonometri.

Siswa sudah mampu memahami konsep perbandingan trigonometri pada sudut-sudut istimewa tetapi masih ada kekeliruan.

Siswa sudah mampu memahami konsep dalil phytagoras.

Siswa belum mampu memahami konsep trigonometri pada segitiga.

Siswa sudah mampu memahami konsep perbandingan trigonometri.

Siswa belum memahami rumus identitas trigonometri.

Siswa sudah mmapu memahami konsep sistem koordinat cartesius.

Siswa sudah mampu memahami konsep kuadran pada sistem koordinat cartesius

Siswa sudah mampu memahami konsep suatu sudut pada sistem koordinat cartesius.

Siswa sudah mampu memahami rumus pada penerapan trigonometri dalam kehidupan sehari-hari.

Siswa sudah mampu memahami 
paham konsep penerapan trigonometri dalam

kehidupan sehari-hari. konsep penerapan trigonometri dalam kehidupan sehari-hari tetapi masih ada kekelituan.

\section{Tahap Analisis Retrosfektif}

Berdasarkan hasil analisis uji learning obstacle sebelum desain didaktis hipotesis diimplementasikan yang diujikan pada 18 siswa terdapat 15 hambatan belajar siswa yang ditemukan oleh peneliti. Dari 15 hambatan belajar siswa tersebut setelah desain didaktis hipotesis diimplementasikan dan dilakukan analisis uji learning obstacle yang diujikan pada 21 siswa ternyata hambatan tersebut menjadi berkurang, dari yang sebelumnya ada 15 hambatan belajar setelah implementasi menjadi 11 hambatan belajar. Adapun dari 11 hambatan belajar tersebut semuanya mengalami penurunan. Dari 15 hambatan belajar tersebut peneliti membandingkan hasil preimplementasi dan pascaimplementasi desain didaktis hipotesis agar terlihat secara jelas perbedaannya. Perbandingan hambatan belajar tersebut digambarkan sebagai berikut:

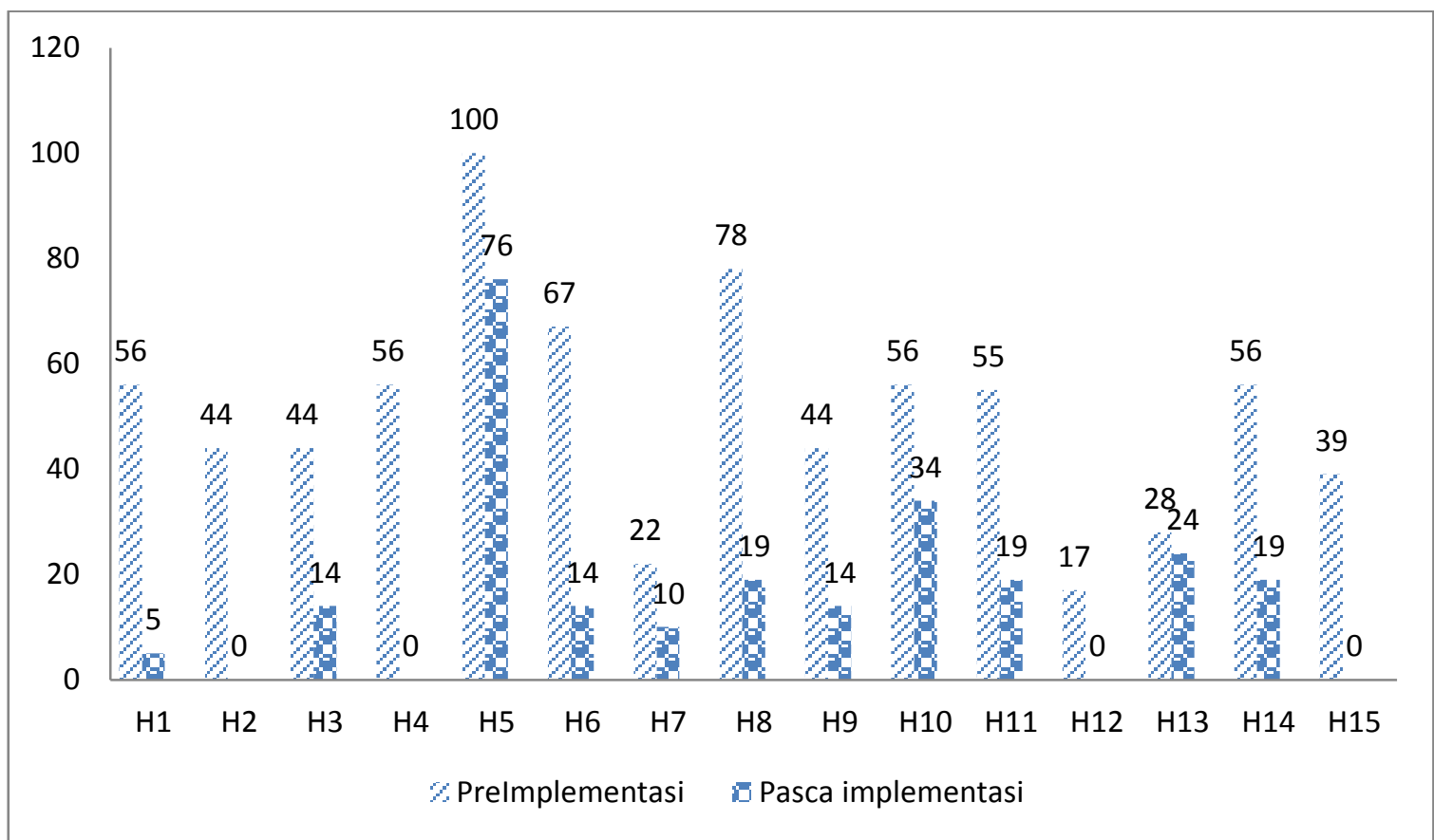

Gambar 2 Perbandingan Hambatan Belajar Siswa Preimplementasi dan Pascaimplementasi

Setelah diperoleh perbandingan learning obstacle antara preimplementasi dan pasca implementasi, selanjutnya peneliti menyusun desain didaktis empirik yang berdasarkan pada masukan ahli terkait dengan RPP dan bahan ajar yang disusun oleh peneliti. Meskipun rancangan desain didaktis hipotesis sudah mampu menurunkan learning obstacle pada setiap indikator soalnya, tetapi agar mengoptimalkan rancangan desain didaktis hipotesis dan learning obstacle dapat diminimalisir dengan maksimal maka dirancanglah desain didaktis empirik.

Adanya penurunan learning obstacle siswa maka desain didaktis hipotesis yang disusun oleh peneliti sudah cukup baik. Akan tetapi dari 15 hambatan belajar siswa baru 4 hambatan belajar yang bisa teratasi secara maksimal sehingga hal tersebut harus menjadi perhatian lebih oleh guru agar tidak terjadi seperti itu. Jika desain didaktis hipotesis yang disusun peneliti sudah cukup baik dan pilihan metode dan strategi pembelajaran yang tepat, serta bahan ajar sudah baik dalam menunjang proses pembelajaran, maka perlunya penguatan terhadap pemahaman siswa dalam memahami rumus yang ada seperti menghapal rumus dengan menghubungkan pada hal-hal yang 
disenangi oleh siswa. Hal tersebut merupakan solusi yang paling tepat dari peneliti untuk menjadikan desain didaktis empirik.

\section{KESIMPULAN}

Berdasarkan analisis dari hasil penelitian dan pembahasan, ditarik kesimpulan bahwa karakteristik learning obstacle siswa yang ditemukan peneliti adalah learning obstacle tipe epistimologis. Learning obstacle tipe epistimologis ini adalah hambatan belajar yang terjadi pada siswa terhadap materi pelajaran. Learning trajectory siswa didapatkan dengan menganalisis alur materi trigonometri yang akan dibuat desain didaktisnya. Alur materi yang akan dibuat desain didaktisnya, yaitu: sudut dan sistem koordinat cartesius, perbandingan trigonometri, rumus identitas trigonometri, rumus jumlah atau selisih fungsi trigonometri, dan penerapan trigonometri. Dari hasil uji learning obstacle sebelum implementasi desain didaktis dan setelah implementasi desain didaktis, peneliti mendapatkan kesimpulan bahwa telah terjadi penurunan learning obstacle sehingga hambatan belajar dapat terminimalisir, bahkan dari 15 hambatan belajar yang ditemukan oleh peneliti sebelum desain didaktis hipotesis diimplementsikan, setelah desain didaktis hipotesis diimplementasikan hambatan tersebut berkurang 4 sehingga hambatan belajar tersebut menjadi 11.

\section{REFERENSI}

Anggraini, N., \& Masykur, R. (2018). Modul Matematika Berdasarkan Model Pembelajaran Problem Based Learning Materi Pokok Trigonometri. Jurnal Matematika, 1(2), 217-228.

Annizar, E. K., \& Suryadi, D. (2016). Desain Didaktis pada Konsep Luas Daerah trapesium untuk Kelas V Sekolah Dasar. Jurnal Pendidikan Dasar, 8(1), 22-33.

Emzir. (2012). Metode Penelitian Kualitatif Analisis Data. Jakarta: PT RajaGrafindo Persada.

Holisin, I. (2016). Pembelajaran Matematika Realistik (PMR). Jurnal Pendidikan Dan Ilmu Pengetabuan, 5(3), 45-49.

Jamaris, M. (2013). Orientasi Baru dalam Psikologi Pendidikan. Bogor: Ghalia Indonesia.

Kusaeri, Lailiyah, S., Arrifadah, Y., \& Hidayati, N. (2018). Proses Berpikir Siswa dalam Menyelesaikan Masalah Matematika Berdasarkan Teori Pemrosesan Informasi. Suska Journal of Mathematics Education, 4(2), 125-141.

Muslim, S. R., Mulyani, E., \& Prabawati, M. N. (2017). Kajian Learning Obstacle Mahasiswa Pendidikan Matematika pada Materi Trigonometri dalam Perkuliahan Kapita Selekta Sekolah Menengah. Jurnal Siliwangi, 3(2), 274-281.

Nasihah, D. (2018). Desain Didaktis Materi Lingkaran pada Madrasah Tsanawiyah.

Nasution, S. (2010). Didaktike Asas-asas Mengajar. Jakarta: Bumi Aksara.

Nikmaturrahmah, D. (2018). Analisis Learning Trajectory Siswa dalam Memecabkan Masalah Matematika Ditinjau dari Gaya Belajar.

Ningsih, S. (2014). Realistic Mathematics Education: Model Alternatif Pembelajaran Matematika Sekolah. Jurnal Pendidikan Matematika, 1(2), 73-94.

Putra, R. W. Y., \& Anggraini, R. (2016). Pengembangan Bahan Ajar Materi Trigonometri Berbantuan Software iMindMap pada Siswa SMA. Pendidikan Matematika, 7(1).

Sanjaya, W. (2008). Kurikulum dan Pembelajaran. Jakarta: Kencana.

Sugiyono. (2013). Metode Penelitian Kuantitatif, Kualitataif, dan R \& D. Bandung: Alfabeta.

Suharsaputra, U. (2012). Metode Penelitian. Bandung: PT Refika Aditama.

Sulistiawati, Suryadi, \& Fatimah. (2015). Desain Didaktis Penalaran Matematis untuk Mengatasi Kesulitan Belajar Siswa SMP pada Luas dan Volume Limas. Jurnal Matematika KreatifInovatif, 6(2), 135-146. 
Suryadi, D. (2010). Metapedadidaktik dan Didactical Design Research (DDR): Sintesis Hasil Pemikiran Berdasarkan Lesson Study. Teori, Paradigma, Prinsip, Dan Pendekatan Pembelajaran MIP A Dalam Konteks Indonesia.

Team Didaktik Metodik Kurikulum IKIP Surabaya. (1987). Pengantar Didaktik Metodik Kurikulum PBM. Jakarta: CV Rajawali.

Wahab, R. (2015). Psikologi Belajar. Jakarta: PT RajaGrafindo Persada.

Yamin, M. (2007). Desain Pembelajaran Berbasais Tingkat Satuan Pendidikan. Jakarta: Gaung Persada Press.

Zad, A. A. A. (2018). Desain Didaktis Luas Daerah Antar Dua Kurva Menggunakan Aplikasi Autograph. 